\title{
Frat is dispensable for canonical Wnt signaling in mammals
}

\section{Renée van Amerongen, ${ }^{1}$ Martijn Nawijn, ${ }^{1}$ Jonathan Franca-Koh, ${ }^{3}$ John Zevenhoven, ${ }^{1}$ Hanneke van der Gulden, ${ }^{1,2}$ Jos Jonkers, ${ }^{1,2}$ and Anton Berns ${ }^{1,4}$}

${ }^{1}$ Division of Molecular Genetics, ${ }^{2}$ Division of Molecular Biology, and the Centre of Biomedical Genetics, The Netherlands Cancer Institute, 1066 CX, Amsterdam, The Netherlands; ${ }^{3}$ Section of Cell and Molecular Biology, Institute of Cancer Research, London SW3 6JB, United Kingdom

Wnt-signal transduction through $\beta$-catenin is thought to require the inhibition of GSK3 by Frat/GBP. To investigate the role of Frat in mammalian development, we have generated mice with targeted mutations in all three murine Frat homologs. We show that Frat is normally expressed at sites of active Wnt signaling. Surprisingly, Frat-deficient mice do not display gross abnormalities. Moreover, canonical Wnt signaling in primary cells is unaffected by the loss of Frat. These studies show that Frat is not an essential component of the canonical Wnt pathway in higher organisms, despite the strict requirement of Frat/GBP for maternal Wnt signaling in Xenopus.

Supplemental material is available at http://www.genesdev.org.

Received September 29, 2004; revised version accepted December 17, 2004.

Canonical Wnt-signal transduction contributes to the control of cell proliferation and differentiation. The turnover of free cytoplasmic $\beta$-catenin is normally regulated through phosphorylation by GSK3, which resides in a complex together with Axin and APC. Binding of extracellular Wnt to Frizzled/LRP transmembrane receptors initiates an intracellular signaling cascade comprising Dishevelled (Dvl) that typically results in the inhibition of GSK3. As a result, unphosphorylated $\beta$-catenin accumulates in the cytoplasm and interacts with TCF/LEF factors to induce transcription of downstream target genes (see Fig. 4A, below). It is generally assumed that Frat competes with Axin for binding to GSK3 and titrates GSK3 away from the scaffolding complex, thus preventing the phosphorylation and degradation of $\beta$-catenin (Li et al. 1999; Farr et al. 2000; Bax et al. 2001; Ferkey and Kimelman 2002; Dajani et al. 2003).

Frat 1 was identified as a proto-oncogene that conveyed selective advantage to cells at later stages of murine T-

[Keywords: Frat; GBP; Wnt; knockout; $\beta$-catenin; glycogen synthase kinase 3]

${ }^{4}$ Corresponding author.

E-MAIL a.berns@nki.nl; FAX 31-20-512-2011.

Article published online ahead of print. Article and publication date are at http://www.genesdev.org/cgi/doi/10.1101/gad.326705. cell lymphomagenesis (Jonkers et al. 1997). Its biological function, however, remained elusive until its Xenopus homolog GBP was isolated as a GSK3-binding protein. Depletion of the endogenous GBP pool in oocytes prevented formation of a normal body axis in developing embryos, and GBP was thus shown to be a core component of the canonical Wnt pathway in Xenopus (Yost et al. 1998; Dominguez and Green 2000; Farr et al. 2000). Like GBP, Frat is able to induce secondary axis formation upon ectopic expression in Xenopus embryos by stabilizing $\beta$-catenin levels (Jonkers et al. 1999), and overexpression of Frat is sufficient to induce $\beta$-catenin/TCFdependent reporter gene activity (van Amerongen et al. 2004). Moreover, the observation that Frat also interacts with Dvl (Li et al. 1999) made Frat an attractive candidate for the "missing-link" bridging signaling from Dvl to GSK3.

Except for the GBP depletion experiment in Xenopus, however, all studies claiming a role for Frat in canonical Wnt signaling have been based on overexpression studies. Therefore, the question whether Frat is a core component of Wnt signaling through $\beta$-catenin in higher vertebrates has so far remained unanswered. To analyze the effects of Frat deficiency on mammalian development and Wnt signaling, we have generated triple-knockout (TKO) mice that lack all three murine Frat homologs. Remarkably, Frat-TKO mice are viable, healthy, and fertile. In addition, in vitro assays on primary Frat-deficient cells show that Wnt signaling through $\beta$-catenin is unaffected by the loss of Frat. Hence, we conclude that Wnt signaling in higher vertebrates is not critically dependent on Frat.

\section{Results and Discussion}

Although the Wnt pathway is conserved in lower organisms, only vertebrates harbor Frat orthologs (Supplementary Fig. 1A). All Frat proteins contain conserved Nand C-terminal regions that have been proposed to constitute functional domains. The $\mathrm{N}$-terminal leucine-rich sequence was shown to drive nuclear export of Frat/ GSK3 complexes (Franca-Koh et al. 2002), whereas sequences in the $\mathrm{C}$ terminus encompass the IKEA-box, which represents the GSK3-binding site (Yost et al. 1998).

We have previously generated Frat1 knockout mice (Jonkers et al. 1999). These mice are healthy and fertile and do not have an obvious phenotype. We have since then cloned Frat 2 and Frat3, which show $68 \%$ and $84 \%$ amino acid identity to Frat1, respectively (Jonkers et al. 1999; van Amerongen et al. 2004). Frat2 and Frat3 show a substantial overlap in expression with Frat1, and either gene might compensate for loss of Frat1 due to functional redundancy between the three homologs. We generated Frat2- and Frat3-knockout mice by replacing most of the respective coding sequences with a lacZ reporter gene (Supplementary Fig. 1B). Similar to Frat1 knockout mice, Frat2- and Frat3-deficient mice appear normal. Frat3 is an imprinted gene, present in mice and rats but not humans. The fact that Frat3-knockout mice are normal (Supplementary Fig. 2) demonstrates that the gene is not causally involved in the Prader-Willi syndrome in mice as has been postulated (Kobayashi et al. 2002). 


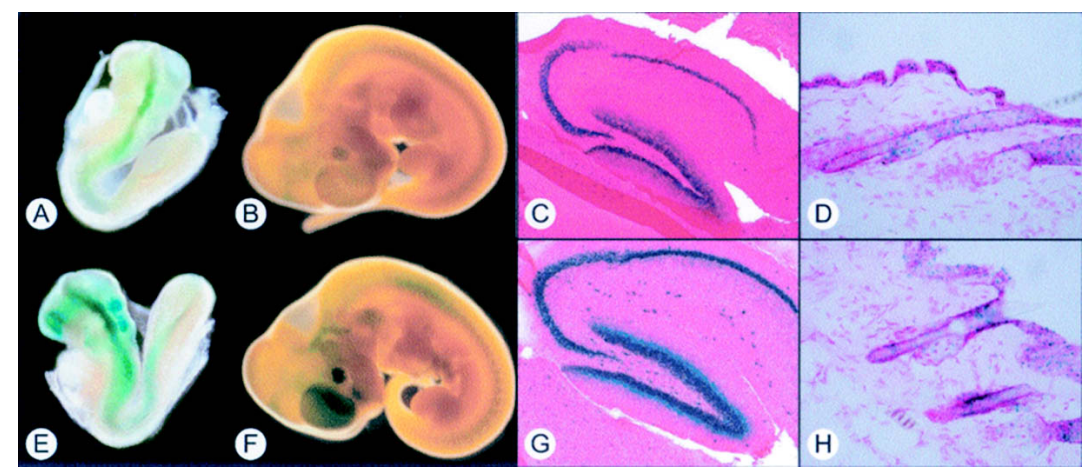

Figure 1. Frat1 and Frat2 show an identical expression pattern in neural and epithelial tissues of developing and adult mice. Comparison of lacZ activity in $\operatorname{Frat1}^{+/ 1 a c Z}(A-D)$ and Frat2 $^{+/ 1 a c Z}(E-H)$ mice reveals overlapping expression between the two homologs. $(A, E)$ Embryonic day 8.5 (E8.5) embryo. $(B, F)$ E10.5 embryo. $(C, G)$ Adult hippocampus. $(D, H)$ Adult skin.

Frat1 is expressed in a broad range of neural and epithelial tissues (Jonkers et al. 1999; Saitoh et al. 2001, 2002; Freemantle et al. 2002; van Amerongen et al. 2004). A detailed analysis of the lacZ activity in Frat2 ${ }^{+/ l a c Z}$ mice shows a similar expression pattern (Supplementary Fig. 3; data not shown). In fact, close comparison of lacZ expression in Frat1 $1^{+/ l a c Z}$ and Frat2 ${ }^{+/ l a c Z}$ mice reveals an almost identical expression pattern, suggesting that the two genes are closely coregulated (Fig. 1). It also lends support to the notion that Frat1-deficient mice have no phenotype due to functional redundancy with Frat2, rather than Frat3 (Jonkers et al. 1999). Interestingly, lacZ expression in Frat $1^{+/ 1 a c Z}$ and Frat2 $2^{+/ 1 a c Z}$ mice shows a significant overlap with that of BAT-gal transgenic mice (Supplementary Fig. 3), which serve as a readout for canonical Wnt signaling (Maretto et al. 2003). Thus, endogenous Frat expression closely matches the in vivo pattern of $\beta$-catenin/TCF activity, in agreement with its presumptive role in canonical Wnt signaling.

Surprisingly, Frat-TKO mice were born at the expected Mendelian ratios from intercrosses of Frat triple-heterozygous mice. TKO mice thrived to old age comparable to littermate controls. In addition, no anatomical abnormalities were observed during microscopic analysis of histologic tissue sections (data not shown).

Based on the design of the targeting vectors, all knockout alleles have lost the Frat-coding sequences starting at the initiation codon and extending beyond the conserved domain containing the binding site for GSK3. No functional proteins can therefore be expressed from the remaining sequences of these intronless genes. Since endogenous Frat proteins cannot be readily detected, we analyzed the targeted loci by RT-PCR (Supplementary Fig. 1D). Expression analysis with primers located in the $3^{\prime}$-UTR revealed read-through in the Frat1 and the Frat2 knockout alleles, despite the presence of a poly(A) sequence in the targeting cassette. However, RT-PCR with primers located in the coding region revealed that no Frat1, Frat2, or Frat 3 coding sequences were transcribed in Frat-TKO mice, whereas Frat expression was readily detected in heterozygous littermate controls, confirming that Frat-TKO mice have lost expression of all Frat-coding sequences. In Xenopus the maternal pool of GBP is required for Wnt signaling in early development. To rule out any effects of maternal or paternal Frat in early embryonic Wnt signaling, we also mated Frat-TKO mice.
Both male and female TKO mice produced healthy offspring in crosses to wild-type mice as well as in homozygous intercrosses (data not shown).

Wnt signaling, converging on the activation of LEF/TCF transcription factors, is essential for hematopoietic stem-cell renewal and defined stages of T-cell and B-cell differentiation /Verbeek et al. 1995; Okamura et al. 1998; Schilham et al. 1998; Reya et al. 2000, 2003; Staal and Clevers 2000). To characterize endogenous Frat expression during lymphoid differentiation, we visualized $\beta$-galactosidase activity encoded by the lac $Z$ knockin alleles by flow cytometry (Table 1; Supplementary Fig. 4). Staining patterns between Frat1 $1^{+/ l a c Z}$ and Frat2 ${ }^{+ \text {llacZ }}$ mice were identical (data not shown). During T-cell differentiation, Frat expression is strongly induced in DN2 cells, which is the first subpopulation of cells committed to the T-cell lineage, and maintained throughout DN3 and DN4. Thus, Frat is expressed prior to the stages at which $\mathrm{T}$-cell differentiation is severely affected in the absence of TCF/LEF (DN3). During lineage commitment to CD4 and CD8 T-cells, low levels of Frat expression are maintained only in CD4 T-cells. In B-cell differentiation, Frat expression is mainly observed in immature B-cells that do not yet express IgM on the cell surface (Supplementary Fig. 4B; data not shown). Taken together, these data indicate that Frat is expressed at defined stages of lymphocyte differentiation. Moreover, the expression pattern largely overlaps with stages that display functional $\beta$-catenin/TCF activity.

Surprisingly, analysis of Frat-TKO mice did not reveal changes in lymphocyte differentiation, as judged by the presence and the relative numbers of all major subpopulations of immature B-cells and T-cells in bone marrow and thymus. Moreover, mature B-cells and T-cells are present in normal numbers in the peripheral organs in Frat-deficient mice (Supplementary Fig. 5; data not shown). Together with the recent observation that the conditional inactivation of $\beta$-catenin in early bone-

Table 1. Frat is expressed in immature lymphoid progenitors

\begin{tabular}{ccrrr}
\hline \multicolumn{2}{c}{ T-cells (thymus) } & & \multicolumn{2}{c}{ B-cells (bone marrow) } \\
\cline { 5 - 5 } Population & $\begin{array}{c}\% \mathrm{FDG}^{+} \\
\text {cells }\end{array}$ & & Population & $\begin{array}{c}\% \mathrm{FDG}^{+} \\
\text {cells }\end{array}$ \\
\hline All thymocytes & $49 \%$ & & Pre-B-cells & $12 \%$ \\
CD4/CD8 DN & $18 \%$ & & B220lo cells & $47 \%$ \\
DN1 & $5 \%$ & & B220hi cells & $6 \%$ \\
DN2 & $61 \%$ & & & \\
DN3 & $40 \%$ & & \\
DN4 & $43 \%$ & & \\
CD4/CD8 DP & $57 \%$ & & \\
CD4lo/CD8lo & $57 \%$ & & \\
CD4 SP & $37 \%$ & & \\
CD8 SP & $18 \%$ & & \\
\hline
\end{tabular}

Flow cytometry with a fluorigenic lacZ substrate (FDG) on single-cell suspensions from thymus and bone marrow from Frat $^{+/ 1 a c Z}$ mice shows expression of Frat in immature T-cells and B-cells. 


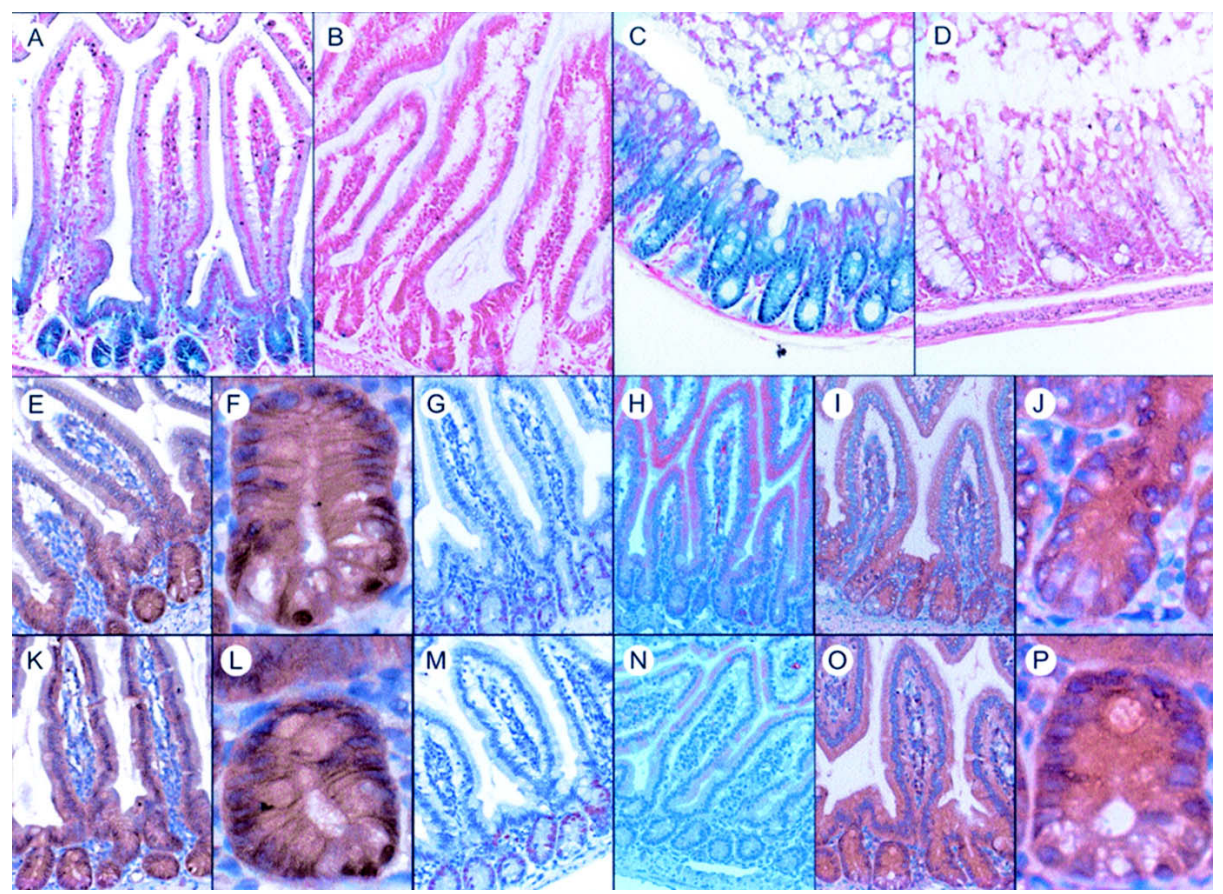

Figure 2. Loss of Frat does not affect the intestinal Wnt gradient. $(A-D)$ LacZ staining on duodenum $(A, B)$ and colon $(C, D)$ shows that Frat2 expression is restricted to intestinal crypt cells. $(A, C)$ Frat2 $^{+/ l a c Z} .(B, D)$ Littermate control. $(E-P)$ The expression of different Wntrelated markers is unchanged in Frat-TKO intestine. $(E-J)$ Frat-TKO. $(K-P)$ Littermate control. $(E, K) \beta$-Catenin, $40 \times$. $F$ and $L$ are close-ups of crypts depicted in $E$ and $K$, respectively. $(G, M)$ Ki67, 40×. $(H, N)$ EphrinB1, 40×. $(I, O)$ EphB2, 40×. $J$ and $P$ are close-ups of crypts depicted in $I$ and $O$, respectively.

marrow progenitors does not impair hematopoiesis and lymphopoiesis (Cobas et al. 2004), and given that SFRP Wnt inhibitors impair T-cell differentiation in a fashion similar to loss of TCF/LEF (Staal et al. 2001), these data indicate that Wnt signaling is essential for the maintenance of cell numbers in the hematopoietic compartment, but not critically dependent on the regulation of GSK3 by Frat or on the activation of $\beta$-catenin.

Extensive studies regarding the distribution and activity of Wnt-pathway components in the intestine has shown that canonical Wnt signaling is required for crypt and villus architecture and for epithelial proliferation (Batlle et al. 2002; Pinto et al. 2003). The overall picture that has formed from these studies is that active Wnt signaling, defined by the presence of nuclear $\beta$-catenin, is restricted to crypts where cells maintain a proliferative and undifferentiated phenotype. Cells lose free $\beta$-catenin as they move up the villus and differentiate. The resulting gradient of canonical Wnt signaling ensures the proper cues for proliferation, differentiation, and migration of intestinal epithelial cells along the villus axis.

LacZ activity in the intestine of adult Frat $1^{+/ \text {lac } Z}$ and Frat2 $^{+/ 1 a c Z}$ animals (Fig. 2A-D; data not shown) provides the most striking example of Frat expression coinciding with Wnt/ $\beta$-catenin activity. Both in the small and large intestine, Frat expression is restricted to the crypts. Nevertheless, we found no changes in the level or localization of $\beta$-catenin and several additional proliferation and differentiation markers in the intestinal epithelium of TKO mice (Fig. 2E-P). Nuclear $\beta$-catenin was observed exclusively in the bottom-most cells of the crypt. Likewise, no changes were seen in the localization or number of cells that stained with the proliferation marker Ki67.
In addition, the EphB2/EphrinB1 gradients were unaffected in TKO mice. Hence, we conclude that loss of Frat does not affect the delicate balance between proliferation and differentiation in the mouse intestine, despite the fact that it is expressed at sites that display Wnt-pathway activity.

To study whether Frat modulates the threshold at which an upstream Wnt signal activates downstream pathway components, we isolated primary fibroblasts (MEFs), in which Frat mRNA is readily detectable, from E13.5 TKO embryos and control littermates. There was no difference in growth rate between the different genotypes when the cells were cultured in a $3 \mathrm{~T} 3$ protocol (data not shown), allowing for a direct comparison between Frat-proficient and Frat-deficient cells in several in vitro assays. Canonical Wnt-signal transduction is activated in control and TKO MEFs after stimulation with Wnt3A-conditioned medium (CM) (Fig. 3A) as evidenced by the accumulation of unphosphorylated $\beta$-catenin (van Noort et al. 2002). We next transfected the cells with the TOPFLASH luciferase reporter, which allows a quantifiable readout of $\beta$-catenin/TCF-dependent gene activity (Molenaar et al. 1996). Control and TKO cells show comparable levels of reporter gene activation in response to Wnt3A-CM (Fig. 3B). To determine whether canonical Wnt signaling is activated less efficiently in the absence of Frat, we exposed the cells to increasing concentrations of Wnt3A-CM and analyzed the nuclear translocation of $\beta$-catenin by immunofluorescence (Fig. 3C). Nuclear $\beta$-catenin accumulates after stimulation with a similar dilution of CM in control and TKO cells. Thus, FratTKO cells are as sensitive and as responsive to stimulation with Wnt3A-CM as are cells isolated from control littermates. 
van Amerongen et al.

A

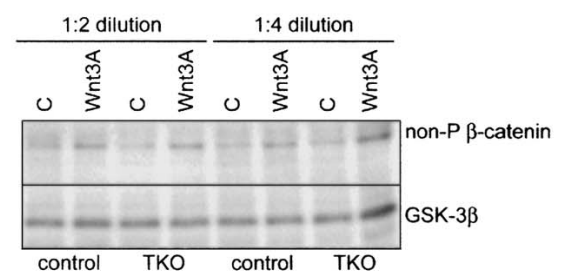

B

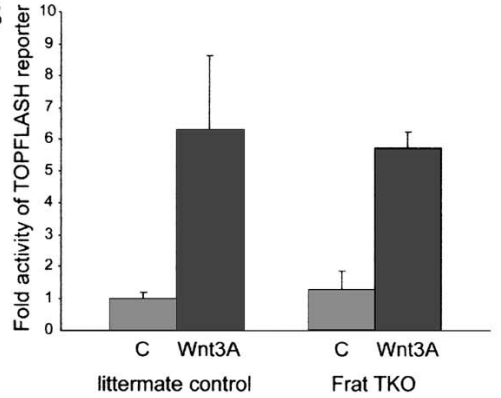

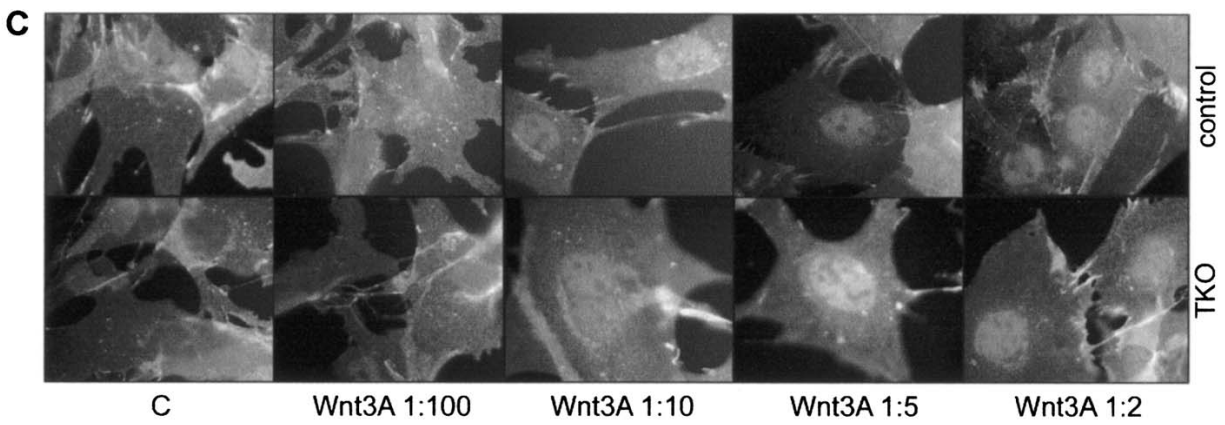

Figure 3. Sensitivity to Wnt ligand and the $\beta$-catenin/TCF response are unimpaired in Frat-TKO cells. TKO and littermate control MEFs were stimulated with control L-cell (lanes labeled C) or Wnt3A-CM (Wnt3A). Activation of canonical Wnt signaling was determined by Western blot analysis of unphosphorylated $\beta$-catenin $(A)$, TOPFLASH luciferase reporter activity (shown are the averages of two experiments on independent MEF isolates, each performed in triplicate) $(B)$, and immunofluorescence to visualize the nuclear accumulation of $\beta$-catenin following titration of different dilutions of Wnt3A-CM (ranging from 1:100 to 1:2) (C).

The observation that Frat-TKO animals do not show perturbations in Wnt-signal transduction might be explained in several ways. First of all, the requirement for GBP in the maternal Wnt pathway in Xenopus might reflect a species-specific phenomenon. The effects of Frat deficiency in higher organisms might be less severe due to more complex and additional regulatory mechanisms or parallel pathways. Alternatively, functional compensation during development may have limited the effects of Frat loss. As both the evidence for the requirement of a maternal Wnt pathway in axis determination in zebrafish (Sumoy et al. 1999; Nojima et al. 2004) as well as the genetic tools allowing manipulation of its genome (Anderson and Ingham 2003; Wienholds et al. 2003) begin to accumulate, it will be interesting to see whether the phenotype described in Xenopus will be recapitulated in zebrafish upon the abolishment of Frat/GBP function. Secondly, Frat might be required for a limited and specific subset of Wnt $/ \beta$-catenin-dependent processes, not causing anatomical abnormalities. Given the high levels of Frat expression in brain and spinal ganglia, additional studies are needed to determine whether, for example, more complex neurological behavior is disturbed in Frat triple-knockout mice. Such a phenotype would not be unprecedented for mice lacking Wnt-pathway components, since mice deficient for Dvll also have a subtle phenotype that results in defects in social behavior (Lijam et al. 1997; Long et al. 2004). In the third place, Frat might be recruited under specific circumstances to increase the efficiency of signal transduction through $\beta$-catenin/TCF or feed into the Wnt pathway from a parallel route independent from Wnt-ligand stimulation (Fig. 4B, left). Finally, despite the fact that Frat is a potent activator of canonical Wnt signaling upon overexpression, it is possible that its endogenous function is related to one of the numerous other GSK3dependent cellular activities (Fig. 4B, right). Whatever the outcome, the Frat-TKO mice provide a powerful system to explore all these possible scenarios. In summary, based on our observations that Frat-TKO mice do not present with overt defects and that Frat-TKO cells are as sensitive and as responsive to an external Wnt stimulus as control cells, we conclude that, in spite of its strong evolutionary conservation, Frat is not a crucial core component of the canonical Wnt-signaling cascade in higher organisms.

\section{Materials and methods}

\section{Generation of Frat-knockout mice}

Frat2 and Frat3 single-knockout mice were generated analogous to Frat1knockout mice (Jonkers et al. 1999). Most of the coding sequence was replaced by a knockout cassette containing a promoterless lacZ-reporter gene followed by a selection cassette, resulting in lacZ-reporter gene expression under control of the endogenous Frat promoter. Gene targeting in embryonic stem (ES) cells was performed as described (Jonkers et al. 1999). Details on the construction of targeting vectors and the generation of Frat-knockout mice are provided in the Supplemental Material.

\section{LacZ analysis}

To detect lacZ activity, stainings were performed according to Hogan (1994) with minor modifications (see Supplemental Material).

\section{Cell culture and transfections}

Primary MEFs were isolated and cultured according to Jacobs et al. (1999) and propagated according to a $3 \mathrm{~T} 3$ protocol. Cells were grown in Dulbecco's modified Eagle's medium supplemented with $10 \%$ fetal bovine serum, glutamine, penicillin/streptomycin (GIBCO), and $50 \mu \mathrm{M} \beta$-mercaptoethanol under $5 \% \mathrm{CO}_{2}$ at $37^{\circ} \mathrm{C}$ in humidifying conditions.

On the day prior to transfection cells were plated in 12-well tissue culture plates. Cells were transfected with 0.5-1 $\mu$ g DNA per well using FuGene (Roche). For each transfection $200 \mathrm{ng}$ of TOPFLASH, $100 \mathrm{ng}$ of 
A

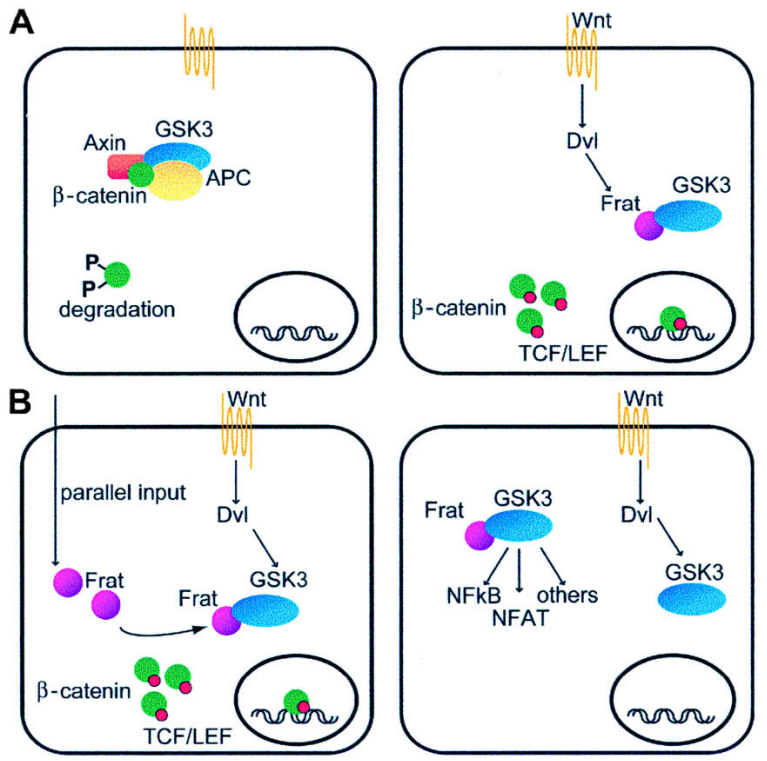

Figure 4. Model for the physiological role of Frat. (A) Current model of canonical Wnt-signal transduction. See text for details. $(B)$ Several models could explain the observation that Frat is not critically required for canonical Wnt signaling in mammals. (Left) Frat might be induced under specific conditions or it might feed into the canonical Wnt pathway from a parallel route independent from upstream Wnt signals. (Right) Alternatively, Frat might be involved in any of the numerous other GSK3-dependent cellular activities, such as the NFkB and NFAT signaling pathways.

Renilla, $100 \mathrm{ng}$ of human TCF4, and $100 \mathrm{ng}$ of GFP were cotransfected. At $24 \mathrm{~h}$ after transfection, a 1:4 dilution of Wnt3A- or L-cell-conditioned medium was added to the cells.

L-cells and L-cells stably expressing Wnt3A were a gift from Dr. Trevor Dale (ICR, London, UK), and conditioned medium was prepared as described previously (Shibamoto et al. 1998). Cells were harvested $48 \mathrm{~h}$ after transfection and analyzed with the dual luciferase assay (Promega) according to the manufacturer's instructions in a Lumat LB 9507 Luminometer (Berthold Technologies).

\section{Western blotting}

Primary MEFs were grown for $24 \mathrm{~h}$ in the presence of Wnt3A- or L-cellconditioned media and lysed in RIPA buffer supplemented with protease inhibitors (Roche). Protein concentration was determined using a colorimetric assay (Bio-Rad), and equal amounts of protein were run on a $10 \%$ SDS-PAGE gel and analyzed on Western blot using ECL (Pierce). Antibodies were used recognizing GSK-3 $\beta$ (1:2500; Transduction Laboratories) or nonphosphorylated $\beta$-catenin (8E4, 1:1000; Alexis). The secondary antibody was goat-anti-mouse-HRP (1:5000; Biosource).

\section{Immunofluorescence}

Cells were plated on glass chamber slides and stimulated with Wnt $3 \mathrm{~A}$ - or L-cell-conditioned medium for $24 \mathrm{~h}$. Cells were fixed in $4 \%$ paraformaldehyde, permeabilized with $0.2 \%$ Triton X-100, and incubated with a primary antibody recognizing $\beta$-catenin (1:500; Transduction Laboratories) and a FITC-conjugated secondary antibody (1:500; Molecular Probes).

\section{Immunohistochemistry}

Details on immunohistochemistry are provided in the Supplemental Material.

\section{Flow cytometry}

Single-cell suspensions were isolated from thymus, spleen, and bone marrow, incubated with appropriate antibodies and analyzed by flow cytometry. Flow cytometric analysis of lacZ activity was performed as previously described (Hendriks et al. 1999). A list of antibodies is provided in the Supplemental Material.

\section{Acknowledgments}

We thank Karin van Veen and Karin van't Woudt for blastocyst injections, Fina van de Ahé and Marcelle Treur-Mulder for help with genotyping, the staff of the NKI animal facility for mouse husbandry, and the histology lab. We thank the histology department for the generation of numerous cryosections; Evert van Garderen, Ji-Ying Song, and Martin van der Valk for histologic analysis; Lauran Oomen for help with digital microscopy; and Dr. Trevor Dale for L-cells to generate Wnt3A-conditioned medium. This work is supported by a grant from the Centre of Biomedical Genetics (CBG).

\section{References}

Anderson, K.V. and Ingham, P.W. 2003. The transformation of the model organism: A decade of developmental genetics. Nat. Genet. 33 Suppl: 285-293.

Batlle, E., Henderson, J.T., Beghtel, H., van den Born, M.M., Sancho, E., Huls, G., Meeldijk, J., Robertson, J., van de Wetering, M., Pawson, T., et al. 2002. $\beta$-Catenin and TCF mediate cell positioning in the intestinal epithelium by controlling the expression of EphB/ephrinB. Cell 111: 251-263.

Bax, B., Carter, P.S., Lewis, C., Guy, A.R., Bridges, A., Tanner, R., Pettman, G., Mannix, C., Culbert, A.A., Brown, M.J., et al. 2001. The structure of phosphorylated GSK-3 $\beta$ complexed with a peptide, FRATtide, that inhibits $\beta$-catenin phosphorylation. Structure (Camb) 9: 1143-1152.

Cobas, M., Wilson, A., Ernst, B., Mancini, S.J., MacDonald, H.R., Kemler, R., and Radtke, F. 2004. $\beta$-Catenin is dispensable for hematopoiesis and lymphopoiesis. J. Exp. Med. 199: 221-229.

Dajani, R., Fraser, E., Roe, S.M., Yeo, M., Good, V.M., Thompson, V., Dale, T.C., and Pearl, L.H. 2003. Structural basis for recruitment of glycogen synthase kinase $3 \beta$ to the axin-APC scaffold complex. $E M B O ~ J .22:$ 494-501.

Dominguez, I. and Green, J.B. 2000. Dorsal downregulation of GSK3 $\beta$ by a non-Wnt-like mechanism is an early molecular consequence of cortical rotation in early Xenopus embryos. Development 127: 861-868.

Farr III, G.H., Ferkey, D.M., Yost, C., Pierce, S.B., Weaver, C., and Kimelman, D. 2000. Interaction among GSK-3, GBP, axin, and APC in Xenopus axis specification. J. Cell Biol. 148: 691-702.

Ferkey, D.M. and Kimelman, D. 2002. Glycogen synthase kinase-3 $\beta$ mutagenesis identifies a common binding domain for GBP and axin. J. Biol. Chem. 277: 16147-16152.

Franca-Koh, J., Yeo, M., Fraser, E., Young, N., and Dale, T.C. 2002. The regulation of glycogen synthase kinase-3 nuclear export by Frat/GBP. I. Biol. Chem. 277: 43844-43848.

Freemantle, S.J., Portland, H.B., Ewings, K., Dmitrovsky, F., DiPetrillo, K., Spinella, M.J., and Dmitrovsky, E. 2002. Characterization and tissue-specific expression of human GSK-3-binding proteins FRAT1 and FRAT2. Gene 291: 17-27.

Hendriks, R.W., Nawijn, M.C., Engel, J.D., van Doorninck, H., Grosveld, F., and Karis, A. 1999. Expression of the transcription factor GATA-3 is required for the development of the earliest $\mathrm{T}$ cell progenitors and correlates with stages of cellular proliferation in the thymus. Eur. $J$. Immunol. 29: 1912-1918.

Hogan, B. 1994. Manipulating the mouse embryo: A laboratory manual. Cold Spring Harbor Laboratory Press, Cold Spring Harbor, NY.

Jacobs, J.J., Kieboom, K., Marino, S., DePinho, R.A., and van Lohuizen, M. 1999. The oncogene and Polycomb-group gene bmi-1 regulates cell proliferation and senescence through the ink4a locus. Nature 397: 164-168.

Jonkers, J., Korswagen, H.C., Acton, D., Breuer, M., and Berns, A. 1997. Activation of a novel proto-oncogene, Frat1, contributes to progression of mouse T-cell lymphomas. EMBO J. 16: 441-450.

Jonkers, J., van Amerongen, R., van der Valk, M., Robanus-Maandag, E., Molenaar, M., Destree, O., and Berns, A. 1999. In vivo analysis of Frat1 deficiency suggests compensatory activity of Frat3. Mech. Dev. 88: 183-194.

Kobayashi, S., Kohda, T., Ichikawa, H., Ogura, A., Ohki, M., KanekoIshino, T., and Ishino, F. 2002. Paternal expression of a novel im- 
van Amerongen et al.

printed gene, Peg12/Frat3, in the mouse 7C region homologous to the Prader-Willi syndrome region. Biochem. Biophys. Res. Commun. 290: 403-408.

Li, L., Yuan, H., Weaver, C.D., Mao, J., Farr III, G.H., Sussman, D.J., Jonkers, J., Kimelman, D., and Wu, D. 1999. Axin and Frat1 interact with dvl and GSK, bridging Dvl to GSK in Wnt-mediated regulation of LEF-1. EMBO I. 18: 4233-4240.

Lijam, N., Paylor, R., McDonald, M.P., Crawley, J.N., Deng, C.X., Herrup, K., Stevens, K.E., Maccaferri, G., McBain, C.J., Sussman, D.J., et al. 1997. Social interaction and sensorimotor gating abnormalities in mice lacking Dvl1. Cell 90: 895-905.

Long, J.M., LaPorte, P., Paylor, R., and Wynshaw-Boris, A. 2004. Expanded characterization of the social interaction abnormalities in mice lacking Dvl1. Genes Brain Behav. 3: 51-62.

Maretto, S., Cordenonsi, M., Dupont, S., Braghetta, P., Broccoli, V., Hassan, A.B., Volpin, D., Bressan, G.M., and Piccolo, S. 2003. Mapping Wnt/ $\beta$-catenin signaling during mouse development and in colorectal tumors. Proc. Nat1. Acad. Sci. 100: 3299-3304.

Molenaar, M., van de Wetering, M., Oosterwegel, M., Peterson-Maduro, J., Godsave, S., Korinek, V., Roose, J., Destree, O., and Clevers, H 1996. XTcf-3 transcription factor mediates $\beta$-catenin-induced axis formation in Xenopus embryos. Cell 86: 391-399.

Nojima, H., Shimizu, T., Kim, C.H., Yabe, T., Bae, Y.K., Muraoka, O., Hirata, T., Chitnis, A., Hirano, T., and Hibi, M. 2004. Genetic evidence for involvement of maternally derived Wnt canonical signaling in dorsal determination in zebrafish. Mech. Dev. 121: 371-386.

Okamura, R.M., Sigvardsson, M., Galceran, J., Verbeek, S., Clevers, H., and Grosschedl, R. 1998. Redundant regulation of T cell differentiation and TCR $\alpha$ gene expression by the transcription factors LEF-1 and TCF-1. Immunity 8: 11-20.

Pinto, D., Gregorieff, A., Begthel, H., and Clevers, H. 2003. Canonical Wnt signals are essential for homeostasis of the intestinal epithelium. Genes \& Dev. 17: 1709-1713.

Reya, T., O'Riordan, M., Okamura, R., Devaney, E., Willert, K., Nusse, R., and Grosschedl, R. 2000. Wnt signaling regulates B lymphocyte proliferation through a LEF-1 dependent mechanism. Immunity 13: $15-24$.

Reya, T., Duncan, A.W., Ailles, L., Domen, J., Scherer, D.C., Willert, K. Hintz, L., Nusse, R., and Weissman, I.L. 2003. A role for Wnt signalling in self-renewal of haematopoietic stem cells. Nature 423: 409414.

Saitoh, T., Moriwaki, J., Koike, J., Takagi, A., Miwa, T., Shiokawa, K., and Katoh, M. 2001. Molecular cloning and characterization of FRAT2, encoding a positive regulator of the WNT signaling pathway. Biochem. Biophys. Res. Commun. 281: 815-820.

Saitoh, T., Mine, T., and Katoh, M. 2002. Molecular cloning and expression of proto-oncogene FRAT1 in human cancer. Int. J. Oncol. 20 785-789.

Schilham, M.W., Wilson, A., Moerer, P., Benaissa-Trouw, B.J., Cumano, A., and Clevers, H.C. 1998. Critical involvement of Tcf-1 in expansion of thymocytes. I. Immunol. 161: 3984-3991.

Shibamoto, S., Higano, K., Takada, R., Ito, F., Takeichi, M., and Takada S. 1998. Cytoskeletal reorganization by soluble Wnt-3a protein signalling. Genes Cells 3: 659-670.

Staal, F.J. and Clevers, H. 2000. Tcf/Lef transcription factors during Tcell development: Unique and overlapping functions. Hematol. J. 1: 3-6.

Staal, F.J., Meeldijk, J., Moerer, P., Jay, P., van de Weerdt, B.C., Vainio, S., Nolan, G.P., and Clevers, H. 2001. Wnt signaling is required for thymocyte development and activates Tcf-1 mediated transcription. Eur. I. Immunol. 31: 285-293.

Sumoy, L., Kiefer, J., and Kimelman, D. 1999. Conservation of intracellular Wnt signaling components in dorsal-ventral axis formation in zebrafish. Dev. Genes Evol. 209: 48-58.

van Amerongen, R., Van Der Gulden, H., Bleeker, F., Jonkers, J., and Berns, A. 2004. Characterization and functional analysis of the murine Frat2 gene. J. Biol. Chem. 279: 26967-26974.

van Noort, M., Meeldijk, J., van der Zee, R., Destree, O., and Clevers, H. 2002. Wnt signaling controls the phosphorylation status of $\beta$-catenin. J. Biol. Chem. 277: 17901-17905.

Verbeek, S., Izon, D., Hofhuis, F., Robanus-Maandag, E., te Riele, H., van de Wetering, M., Oosterwegel, M., Wilson, A., MacDonald, H.R., and Clevers, H. 1995. An HMG-box-containing T-cell factor required for thymocyte differentiation. Nature 374: 70-74.

Wienholds, E., van Eeden, F., Kosters, M., Mudde, J., Plasterk, R.H., and Cuppen, E. 2003. Efficient target-selected mutagenesis in zebrafish. Genome Res. 13: 2700-2707.

Yost, C., Farr III, G.H., Pierce, S.B., Ferkey, D.M., Chen, M.M., and Kimelman, D. 1998. GBP, an inhibitor of GSK-3, is implicated in Xenopus development and oncogenesis. Cell 93: 1031-1041. 


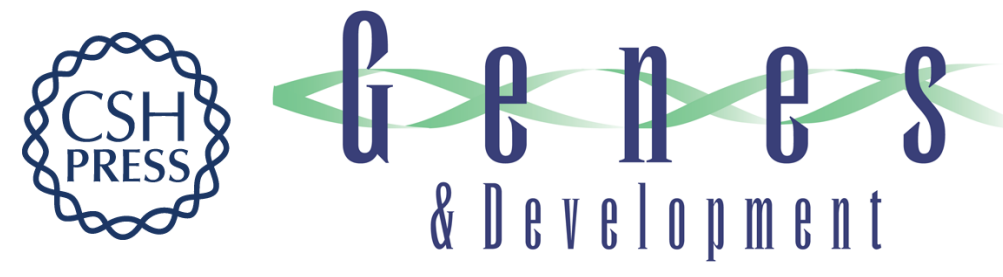

\section{Frat is dispensable for canonical Wnt signaling in mammals}

Renée van Amerongen, Martijn Nawijn, Jonathan Franca-Koh, et al.

Genes Dev. 2005, 19:

Access the most recent version at doi:10.1101/gad.326705

Supplemental

Material

References This article cites 35 articles, 14 of which can be accessed free at: http://genesdev.cshlp.org/content/19/4/425.full.html\#ref-list-1

\section{License}

Email Alerting Service right corner of the article or click here.
http://genesdev.cshlp.org/content/suppl/2005/01/25/gad.326705.DC1

Receive free email alerts when new articles cite this article - sign up in the box at the top

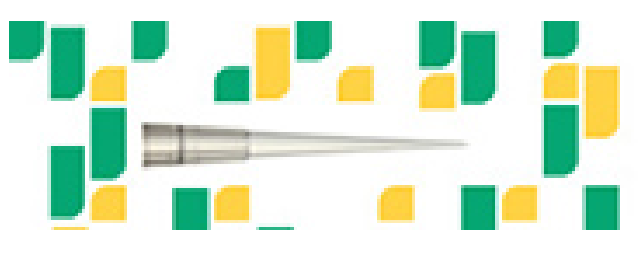

Focused on your science. 